\title{
Article
}

|||||||||||||||||||||||||||||||||| $\mid$

\section{Fixed Point Observations and Characterization of Radioactive Caesium in Tama River}

\author{
Kenta Hagiwara ${ }^{1,2, \dagger}$, Kotaro $\mathrm{OCHI}^{3}$ and Yuya $\mathrm{KoIKE}^{1}$ \\ ${ }^{1}$ Department of Applied Chemistry, Meiji University, \\ ${ }^{2}$ Graduate School of Science and Technology, Meiji University, \\ ${ }^{3}$ Fukushima Environmental Safety Center, Japan Atomic Energy Agency \\ ${ }^{\dagger}$ kenhagi@meiji.ac.jp \\ Received April 1, 2020 \\ Accepted January 28, 2021
}

\begin{abstract}
Behavior of radioactive caesium, derived from Fukushima Dai-ichi Nuclear Power Plant Accident, in river water and sediment investigated during 2012-2016. Concentrations of radioactive caesium in river water and sediment were decreased with time exponentially. The residence half-life of radioactive caesium in the river water and sediment were $0.788-1.50$ year for ${ }^{134} \mathrm{Cs}, 1.22-2.17$ year for ${ }^{137} \mathrm{Cs}$. Any decrease in radioactive caesium concentration in the Tama river is because of weathering effect than radioactive decay. Concentrations of suspended radioactive caesium temporarily increased when sediments were resuspended due to rain. On the other hand, dissolved radioactive caesium is not easily impacted by this factor. Radioactive caesium concentration in sediments was considerably higher than that in river water. It indicated that much of the radioactive caesium in the Tama river existed in the sediments. Sequential extraction, elemental and crystal phase analysis were performed on the sediments and examined the chemical state of radioactive caesium as well as the adsorption mechanism. Radioactive caesium in sediment was present in a stable chemical form, and there is possibility that radioactive caesium was incorporated in biotite.
\end{abstract}

Key Words: radioactive caesium, river water, sediment, fixed point observation, biotite, Fukushima Dai-ichi Nuclear Power Plant Accident

\section{Introduction}

Radioactive caesium $\left({ }^{134} \mathrm{Cs}\right.$ and $\left.{ }^{137} \mathrm{Cs}\right)$ was released into the environment contaminated rivers, ${ }^{1-4)}$ forests, ${ }^{5-7)}$ soils, ${ }^{8-11)}$ and oceans ${ }^{12-14)}$ by Fukushima Dai-ichi Nuclear Power Plant Accident in 2011. It is particularly important to analyze the radioactive caesium in rivers, as it has a major impact on humans and spreads radioactive contamination. Radioactive caesium in water exists as dissolved or suspended form, ${ }^{15-18)}$ and these behaves are differently. Dissolved radioactive caesium exists as caesium ions and hydrated caesium ions, ${ }^{1)}$ and gets transported relatively rapidly through the water due to the speed of water flow, contaminating plants via root uptake. ${ }^{19)}$ While, suspended radioactive caesium is adsorbed onto suspended solids, where secondary contamination due to sediment runoff is a concern. ${ }^{20)}$ If we can elucidate the transport and redistribution of radioactive caesium by understanding the behavior of radioactive caesium in water and sediments, it would aid in decontamination and rapid response efforts during radioactive accidents.

There have been many investigations for radioactive caesium in river water. In the Kuchibuto river (in Fukushima prefecture), the concentration of radioac- 
tive caesium in water was found to be extremely high, i.e. $1470 \mathrm{BqL}^{-1}$ (as of 2011), where dissolved caesium concentration was 1 to $49 \%$ of the total concentration. ${ }^{2)}$ An investigation of the Abukuma river in Fukushima prefecture showed that the concentration of radioactive caesium in water was different in the upstream and downstream areas, and was highly correlated to the air dose rate. ${ }^{3)}$ In terms of sediments, it has been reported that finer particle sizes were associated with higher radioactive caesium concentrations, where radioactive caesium was adsorbed onto minerals such as smectite, mica, and illite. ${ }^{21)}$ However, these investigations were conducted in Fukushima prefecture, where the nuclear accident took place, and there have not been many long-term monitoring studies on the behavior of radioactive caesium in rivers in areas of Japan with lower doses. Therefore, we conducted a long-term monitoring study, from June 2012 to January 2016, of the behavior of radioactive caesium in the Tama river, located over $200 \mathrm{~km}$ from the Fukushima Daiichi nuclear power plant. We performed sequential extraction, as well as elemental and crystal phase analysis, on the sediments and examined the chemical state of radioactive caesium as well as the adsorption mechanism.

\section{Experiment}

\section{$2 \cdot 1 \quad$ Apparatus}

$\gamma$-ray spectrometry was performed with a PGT HPGe detector, a high-purity germanium semiconductor detector, and radioactivity concentrations of ${ }^{134} \mathrm{Cs}$ and ${ }^{137} \mathrm{Cs}$ were calculated from $\gamma$-ray peaks at $604.7 \mathrm{keV}$ and $661.7 \mathrm{keV}$, respectively. Detection efficiency was calculated with a sealed ${ }^{152} \mathrm{Eu}$ radioactive source (Japan Radioisotope Association) and $\mathrm{KCl}$ reagent.22) The radioactivity concentration of sample was corrected based on the sampling date.

A Thermo Scientific Niton XL3t was used for $\mathrm{X}$-ray fluorescence analysis. The X-ray tube is a miniature $\mathrm{Au}$ tube, and the detector is a Si-PIN di- ode. Measurements were taken for $90 \mathrm{~s}$ in the soil analysis mode.

A Rigaku RINT-2500 TTR-III was used for X-ray diffraction analysis. $\mathrm{Cu}$ was used for the $\mathrm{X}$-ray tube, and the tube voltage and current for operation were $50 \mathrm{kV}$ and $300 \mathrm{~mA}$, respectively. Measurement conditions were continuous, with a step width of $0.01^{\circ}$, a measurement angle of $5-45^{\circ}$, and a scan speed of $5^{\circ} \min ^{-1}$.

To measure the conductivity, $\mathrm{pH}$, oxidationreduction potential, dissolved oxygen content, turbidity, and amount of dissolved solids of the river water samples, a HORIBA U-52 multiparameter water quality checker was used. Solid samples were dried using a Yamato DVS-402 Programmable gravity convection oven. For solid-liquid separation, a KOKUSAN H-103 N centrifuge was used.

\subsection{Sediments and river water samples}

River water and sediment samples were collected in Shukugawara, which is the mid-stream area of the Tama river (Fig. 1), between June 7, 2012, and January 26, 2016.

With a polyethylene container, 20 to $100 \mathrm{~L}$ of water was sampled directly from the surface of the river. Samples were filtered with ADVANTEC No. $5 \mathrm{C}$ filter paper with a retained particle size of $1 \mu \mathrm{m}$, and suspended solids were captured. Subsequently, suspended solids were packed in a screw-top polystyrene container (height of $68 \mathrm{~mm}$ and inner diameter of $56 \mathrm{~mm}$ ) with the filter paper, which was the suspended sample. To $5 \mathrm{~L}$ of filtrate, $30 \mathrm{~mL}$ of $12 \mathrm{molL}^{-1} \mathrm{HCl}$ (extra pure grade, Junsei Kagaku) and $2 \mathrm{~g}$ of ammonium phosphomolybdate (AMP; 99\% or more, Yoneyama Yakuhin Kogyo Co., Ltd.) were added, and the sample was then stirred for 1h. ${ }^{23)}$ After overnight incubation, this filtrate was filtered with ADVANTEC No. 5B, with a retained particle size of $4 \mu \mathrm{m}$, to recover AMP with concentrated radioactive caesium. AMP was then packed 
(A)

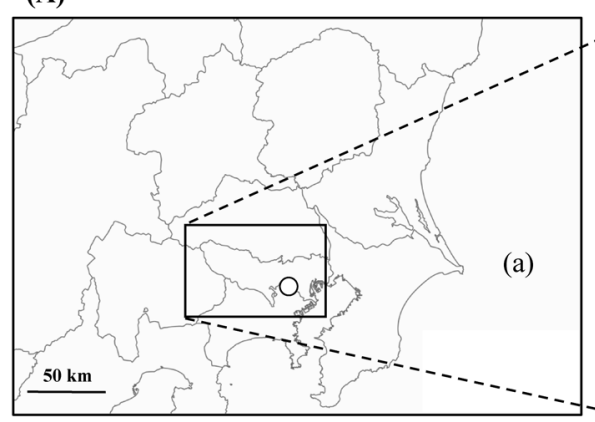

(B)

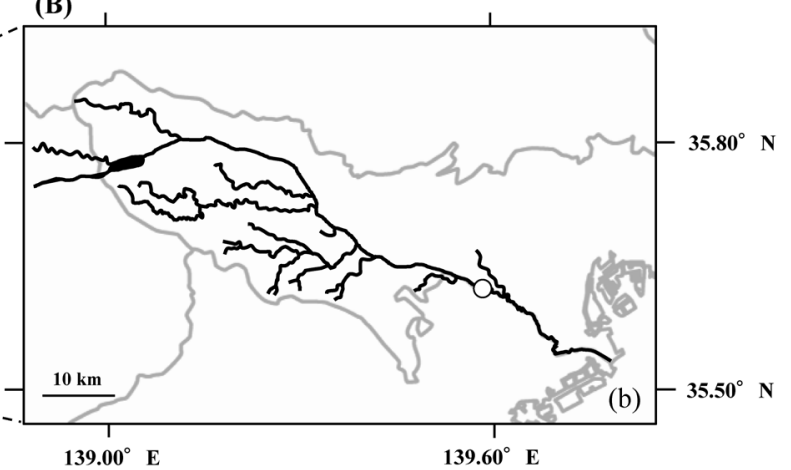

Fig. 1 Map of sampling point, Shukugawara (O). (A): Kanto region, Japan. (B): Tama river watershed. (a): Pacific ocean. (b): Tokyo bay. Black line: Tama river and tributary. Gray line: Prefectural border.

in a screw-top polystyrene container with the filter paper, as the dissolved sample. $\gamma$-ray spectrometry was performed for $48 \mathrm{~h}$ on each sample.

A sediment sample of about $1 \mathrm{~kg}$ was collected using a shovel from the sediment surface layer (less than $5 \mathrm{~cm}$ ) at a water depth of 30 to $50 \mathrm{~cm}$. Samples were dried for $24 \mathrm{~h}$ at $105^{\circ} \mathrm{C}$ in an oven. Subsequently, they were passed through a 2-mm sieve, reduced with the coning and quartering method, and then packed in screw-top polystyrene containers for measurement. $\gamma$-ray spectrometry was performed for $2 \mathrm{~h}$ on each sample.

\subsection{Sequential extraction}

The sequential extraction method, proposed by Tessier et al. ${ }^{24)}$ was applied to the sediment samples. This method fractionates and extracts trace metal elements in samples as ion-exchangeable (IE), bond to carbonates $(\mathrm{CB})$, bond to $\mathrm{Fe}$ and $\mathrm{Mn}$ oxides $(\mathrm{OX})$, bond to organics and sulfide compounds (OB), and residuals (RES). Further, $40 \mathrm{~mL}$ of $1 \mathrm{molL}^{-1} \mathrm{MgCl}_{2}$ aqueous solution was added to $5 \mathrm{~g}$ of dried sediment and stirred for $1 \mathrm{~h}$ at room temperature with a magnetic stirrer (IE). After the IE extraction, $40 \mathrm{~mL}$ of $1 \mathrm{molL}^{-1} \mathrm{CH}_{3} \mathrm{COOH}$ buffer solution, adjusted to a $\mathrm{pH}$ of 5 , was added to the residue and stirred for $6 \mathrm{~h}$ at room temperature $(\mathrm{CB})$. Subsequently, $100 \mathrm{~mL}$ of $0.04 \mathrm{~mol} \mathrm{~L}^{-1} \mathrm{HONH}_{3} \mathrm{Cl}$ aqueous solution was added to the residue, and the sample was heated and stirred for $6 \mathrm{~h}$ at $96^{\circ} \mathrm{C}(\mathrm{OX})$. Further, $15 \mathrm{~mL}$ of $0.02 \mathrm{~mol} \mathrm{~L}^{-1}$ $\mathrm{HNO}_{3}$ and $25 \mathrm{~mL}$ of $30 \% \mathrm{H}_{2} \mathrm{O}_{2}$ aqueous solution was added to the residue after the OX extraction, and then heated and stirred for $3 \mathrm{~h}$ at $85^{\circ} \mathrm{C}$. Then, $25 \mathrm{~mL}$ of $3.2 \mathrm{molL}^{-1} \mathrm{CH}_{3} \mathrm{COONH}_{4}$ aqueous solution, $15 \mathrm{~mL}$ of $0.02 \mathrm{~mol} \mathrm{~L}^{-1} \mathrm{HNO}_{3}$, and $20 \mathrm{~mL}$ of pure water were added, and the sample was stirred for $3 \mathrm{~h}$ at room temperature $(\mathrm{OB})$. The final residue was used as the RES sample and was dried for $24 \mathrm{~h}$ at $85^{\circ} \mathrm{C}$. Each extraction liquid was stirred and centrifuged for $20 \mathrm{~min}$ at $3000 \mathrm{rpm}$ to separate the eluate and residue. The extracted liquid and residue were placed in a screwtop polystyrene container, and $\gamma$-ray spectrometry was performed for $6 \mathrm{~h}$.

Throughout the experiment, extra pure grade reagents ware used.

\section{Results and discussion}

$3 \cdot 1$ Temporal changes in radioactive caesium concentration in river water

Table 1 and Table 2 show the activity concentrations of suspended and dissolved radioactive caesium in Tama river water sampled at Shukugawara during 2012-2015. The activity ratio of ${ }^{134} \mathrm{Cs} /{ }^{137} \mathrm{Cs}$ corrected at the time of March 15, 2011 was 1.04 \pm 0.15 and $0.99 \pm 0.14$ for suspended and dissolved radioactive caesium, respectively, and it was confirmed that the 
Table 1 Activity concentration of suspended radioactive caesium in river water sampled at Shukugawara

\begin{tabular}{|c|c|c|c|}
\hline \multirow{2}{*}{ Sampling date } & \multicolumn{2}{|c|}{ Activity concentration $( \pm 1 \sigma) / \mathrm{mBq} \mathrm{L}^{-1}$} & \multirow{2}{*}{$\begin{array}{l}{ }^{134} \mathrm{Cs} /{ }^{137} \mathrm{Cs} \\
\text { activity ratio** }\end{array}$} \\
\hline & ${ }^{134} \mathrm{Cs}$ & ${ }^{137} \mathrm{Cs}$ & \\
\hline 2013.4 .12 & $0.587 \pm 0.091$ & $0.961 \pm 0.089$ & 1.17 \\
\hline 2013.5 .14 & $0.844 \pm 0.101$ & $1.263 \pm 0.094$ & 1.32 \\
\hline 2013.6.11 & $1.157 \pm 0.110$ & $1.818 \pm 0.115$ & 1.28 \\
\hline 2013.7.11 & $0.595 \pm 0.080$ & $1.079 \pm 0.081$ & 1.14 \\
\hline 2013.8 .2 & $0.665 \pm 0.100$ & $1.654 \pm 0.129$ & 0.848 \\
\hline 2013.9.27 & $0.337 \pm 0.061$ & $0.660 \pm 0.062$ & 1.13 \\
\hline 2013.10 .31 & $0.198 \pm 0.048$ & $0.552 \pm 0.056$ & 0.815 \\
\hline 2013.11 .7 & $0.226 \pm 0.057$ & $0.547 \pm 0.063$ & 0.945 \\
\hline 2013.11 .14 & $0.554 \pm 0.075$ & $1.463 \pm 0.094$ & 0.880 \\
\hline 2013.11 .21 & $0.329 \pm 0.088$ & $0.803 \pm 0.098$ & 0.950 \\
\hline 2014.4 .30 & $0.785 \pm 0.106$ & $2.110 \pm 0.115$ & 0.989 \\
\hline 2014.5.30 & $0.335 \pm 0.067$ & $0.902 \pm 0.071$ & 1.01 \\
\hline 2014.6.27 & $0.579 \pm 0.091$ & $1.397 \pm 0.092$ & 1.16 \\
\hline 2014.7 .29 & $0.454 \pm 0.079$ & $1.219 \pm 0.084$ & 1.07 \\
\hline 2014.9 .16 & $0.629 \pm 0.093$ & $1.704 \pm 0.102$ & 1.10 \\
\hline 2015.1 .29 & $0.169 \pm 0.077$ & $0.497 \pm 0.078$ & 1.14 \\
\hline 2015.3 .12 & $0.179 \pm 0.055$ & $0.675 \pm 0.062$ & 0.925 \\
\hline 2015.5 .22 & $0.350 \pm 0.074$ & $1.064 \pm 0.070$ & 1.22 \\
\hline 2015.6 .10 & $0.301 \pm 0.084$ & $1.088 \pm 0.081$ & 1.04 \\
\hline 2015.7 .14 & $0.232 \pm 0.075$ & $0.997 \pm 0.077$ & 0.904 \\
\hline 2015.8 .26 & $2.166 \pm 0.234$ & $9.959 \pm 0.242$ & 0.875 \\
\hline 2015.9 .12 & $0.179 \pm 0.066$ & $0.907 \pm 0.071$ & 0.806 \\
\hline 2015.10 .21 & $<0.03^{\mathrm{a}}$ & $0.071 \pm 0.020$ & - \\
\hline 2015.11 .25 & $<0.03^{\mathrm{a}}$ & $0.600 \pm 0.059$ & - \\
\hline 2015.12 .23 & $0.145 \pm 0.026$ & $0.523 \pm 0.055$ & 1.23 \\
\hline
\end{tabular}

*Activity concentration was corrected at the time of March 15, 2011.

${ }^{a}$ Not detected.

radioactive caesium was derived from the Fukushima Dai-ichi Nuclear Power Plant Accident. The suspended concentration was lower than the dissolved concentration, indicating that radioactive caesium in Tama river water was mainly in a water-soluble state, such as ions. Fig. 2 shows the temporal changes in suspended radioactive caesium concentrations in river water. Fig. 3 shows the temporal changes in dissolved radioactive caesium concentrations at the same location. The suspended radioactive caesium concentration $\left(C_{\mathrm{Cs}}\right)$ decreased exponentially as a function of the days since the nuclear accident $(d)$; $C_{\mathrm{Cs}-134}=1.67 \mathrm{e}^{-0.00126 d}$ and $C_{\mathrm{Cs}-137}=2.53 \mathrm{e}^{-0.000874 d}$. In the case of the dissolved one, $C_{\mathrm{Cs}-134}=22.9 \mathrm{e}^{-0.00204 d}$ and $C_{\mathrm{Cs}-137}=20.4 \mathrm{e}^{-0.00104 d} \cdot C_{\mathrm{Cs}-134}$ and $C_{\mathrm{Cs}-137}$ are shown by solid and dashed lines, respectively in Figs. 2 and 3. We used Pearson's correlation coefficient $(r)$ in the statistical analysis, which measures the strength and direction of a linear relationship
Table 2 Activity concentration of dissolved radioactive caesium in river water sampled at Shukugawara

\begin{tabular}{|c|c|c|c|}
\hline \multirow{2}{*}{ Sampling date } & \multicolumn{2}{|c|}{ Activity concentration $( \pm 1 \sigma) / \mathrm{mBq} \mathrm{L}^{-1}$} & \multirow{2}{*}{$\begin{array}{l}{ }^{134} \mathrm{Cs} /{ }^{137} \mathrm{Cs} \\
\text { activity ratio* }\end{array}$} \\
\hline & ${ }^{134} \mathrm{Cs}$ & ${ }^{137} \mathrm{Cs}$ & \\
\hline 2012.6 .7 & $14.03 \pm 1.40$ & $17.34 \pm 1.16$ & 1.19 \\
\hline 2012.6 .14 & $11.86 \pm 1.75$ & $15.38 \pm 1.27$ & 1.13 \\
\hline 2012.6 .29 & $8.30 \pm 1.12$ & $11.49 \pm 0.99$ & 1.08 \\
\hline 2012.7.4 & $9.20 \pm 0.92$ & $12.25 \pm 0.80$ & 1.13 \\
\hline 2012.7 .26 & $10.45 \pm 1.18$ & $13.84 \pm 1.03$ & 1.16 \\
\hline 2012.8 .17 & $8.14 \pm 0.82$ & $12.34 \pm 0.77$ & 1.03 \\
\hline 2012.8.29 & $7.98 \pm 0.85$ & $10.58 \pm 0.75$ & 1.19 \\
\hline 2012.9 .20 & $8.50 \pm 0.71$ & $12.20 \pm 0.65$ & 1.12 \\
\hline 2012.10 .10 & $9.02 \pm 1.04$ & $15.50 \pm 1.06$ & 0.953 \\
\hline 2012.10 .23 & $7.89 \pm 0.95$ & $11.81 \pm 0.91$ & 1.11 \\
\hline 2012.11 .13 & $4.24 \pm 0.62$ & $7.84 \pm 0.66$ & 0.911 \\
\hline 2012.11.27 & $7.22 \pm 0.60$ & $11.26 \pm 0.65$ & 1.09 \\
\hline 2012.12 .18 & $9.73 \pm 0.71$ & $16.44 \pm 0.80$ & 1.03 \\
\hline 2013.4 .12 & $2.33 \pm 0.13$ & $5.15 \pm 0.22$ & 0.866 \\
\hline 2013.5 .14 & $5.49 \pm 0.19$ & $10.99 \pm 0.30$ & 0.982 \\
\hline 2013.6 .11 & $2.95 \pm 0.13$ & $6.67 \pm 0.22$ & 0.893 \\
\hline 2013.7.11 & $6.00 \pm 0.21$ & $13.87 \pm 0.36$ & 0.896 \\
\hline 2013.8 .2 & $4.11 \pm 0.17$ & $8.73 \pm 0.27$ & 0.993 \\
\hline 2013.9 .27 & $2.02 \pm 0.14$ & $4.81 \pm 0.23$ & 0.929 \\
\hline 2013.10 .31 & $1.32 \pm 0.09$ & $3.48 \pm 0.17$ & 0.865 \\
\hline 2013.11 .7 & $1.80 \pm 0.10$ & $3.98 \pm 0.17$ & 1.03 \\
\hline 2013.11 .14 & $2.44 \pm 0.13$ & $5.29 \pm 0.21$ & 1.06 \\
\hline 2013.11 .21 & $3.08 \pm 0.16$ & $7.81 \pm 0.27$ & 0.915 \\
\hline 2014.4 .30 & $2.89 \pm 0.15$ & $8.06 \pm 0.27$ & 0.954 \\
\hline 2014.5 .30 & $3.51 \pm 0.16$ & $10.08 \pm 0.29$ & 0.951 \\
\hline 2014.6 .27 & $1.83 \pm 0.12$ & $5.37 \pm 0.22$ & 0.955 \\
\hline 2014.7.29 & $1.62 \pm 0.11$ & $5.65 \pm 0.22$ & 0.823 \\
\hline 2014.9 .16 & $1.82 \pm 0.12$ & $6.61 \pm 0.25$ & 0.824 \\
\hline 2015.1 .29 & $1.19 \pm 0.11$ & $4.34 \pm 0.24$ & 0.924 \\
\hline 2015.3 .12 & $1.34 \pm 0.10$ & $5.19 \pm 0.23$ & 0.900 \\
\hline 2015.5 .22 & $0.77 \pm 0.08$ & $5.72 \pm 0.25$ & 0.497 \\
\hline 2015.6 .10 & $1.34 \pm 0.12$ & $4.83 \pm 0.23$ & 1.05 \\
\hline 2015.7 .14 & $0.93 \pm 0.10$ & $4.13 \pm 0.21$ & 0.878 \\
\hline 2015.8 .26 & $1.10 \pm 0.10$ & $4.01 \pm 0.21$ & 1.10 \\
\hline 2015.9 .12 & $0.26 \pm 0.05$ & $0.90 \pm 0.10$ & 1.20 \\
\hline 2015.10 .21 & $0.88 \pm 0.09$ & $3.29 \pm 0.19$ & 1.13 \\
\hline 2015.11 .25 & $0.87 \pm 0.09$ & $3.89 \pm 0.21$ & 0.967 \\
\hline 2015.12 .23 & $1.57 \pm 0.12$ & $8.05 \pm 0.30$ & 0.866 \\
\hline
\end{tabular}

*Activity concentration was corrected at the time of March 15, 2011.

between two variables $(x, y)$ on a scatterplot, and is given by

$$
r=\frac{n\left(\sum x y\right)-\left(\sum x\right)\left(\sum y\right)}{\sqrt{\left[n \sum x^{2}-\left(\sum x\right)^{2}\right]\left[n \sum y^{2}-\left(\sum y\right)^{2}\right]}}
$$

where $n$ refers to the number of data $(x, y)$. In the case of the suspended radioactive caesium concentration, by inserting $x$ as $d$ and $y$ as $C_{\mathrm{Cs}}, r$ was estimated -0.657 for $C_{\mathrm{Cs}-134}$ and -0.425 for $C_{\mathrm{Cs}-137}$. On the other hand, in the case of the dissolved one, $r$ was -0.910 for $C_{\mathrm{Cs}-134}$ and -0.746 for $C_{\mathrm{Cs}-137}$ which showed a strong correlation. Concentration of sus- 


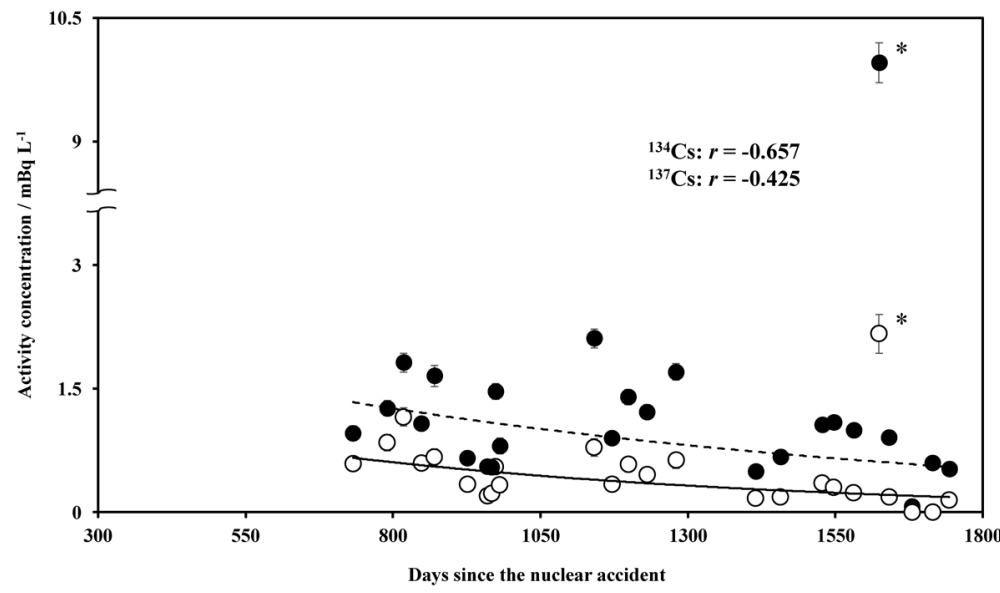

Fig. 2 Temporal changes of suspended ${ }^{134} \mathrm{Cs}(\bigcirc)$ and ${ }^{137} \mathrm{Cs}(\bigcirc)$ concentrations in Tama river water sampled at Shukugawara.

*: Sampled at August 26, 2015. Error bar: Standard deviation.

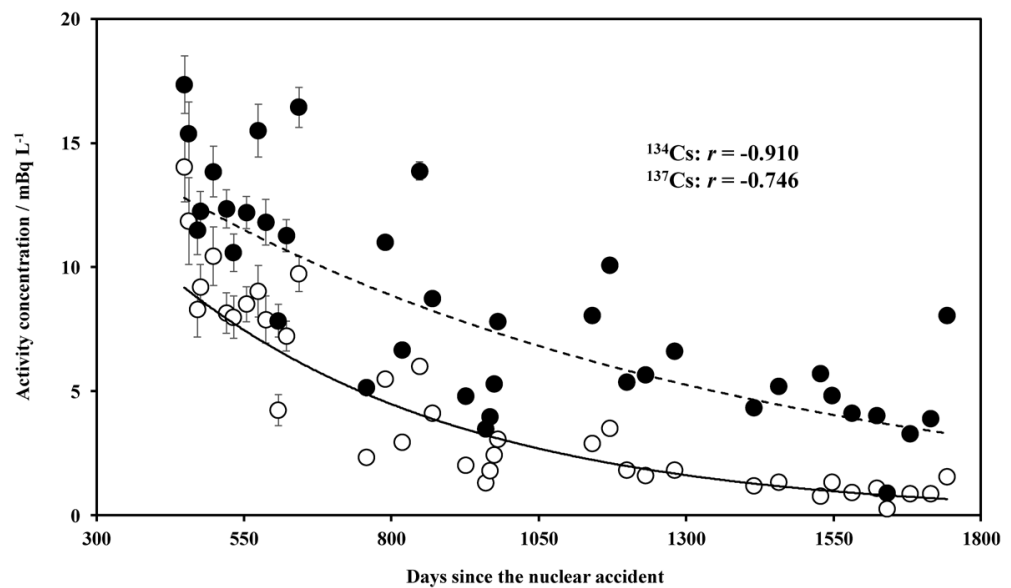

Fig. 3 Temporal changes of dissolved ${ }^{134} \mathrm{Cs}(\bigcirc)$ and ${ }^{137} \mathrm{Cs}(\bullet)$ concentrations in Tama river water sampled at Shukugawara. Error bar: Standard deviation.

pended radioactive caesium temporarily increases when sediments are resuspended due to rain (for example, at August 26, 2015) and there is an inflow of soil and suspended materials from the surrounding environment. This likely caused a little weak correlation with the number of days (since the nuclear accident). On the other hand, dissolved caesium is not easily impacted by these factors; thus, it had a strong correlation with the number of days (since the nuclear accident). According to the correlating equations between the concentrations of radioactive caesium and the number of days (since the nuclear accident), the residence half-life of radioactive caesium in the river water were 1.50 year for suspended ${ }^{134} \mathrm{Cs}, 2.17$ year for suspended ${ }^{137} \mathrm{Cs}, 0.931$ year for dissolved ${ }^{134} \mathrm{Cs}$, and 1.83 year for dissolved ${ }^{137} \mathrm{Cs}$. Since the half-life of ${ }^{134} \mathrm{Cs}$ and ${ }^{137} \mathrm{Cs}$ are 2.06 and 30.1 years, respectively, any decrease in radioactive caesium concentration in the river water was because of weathering effect than radioactive decay. 

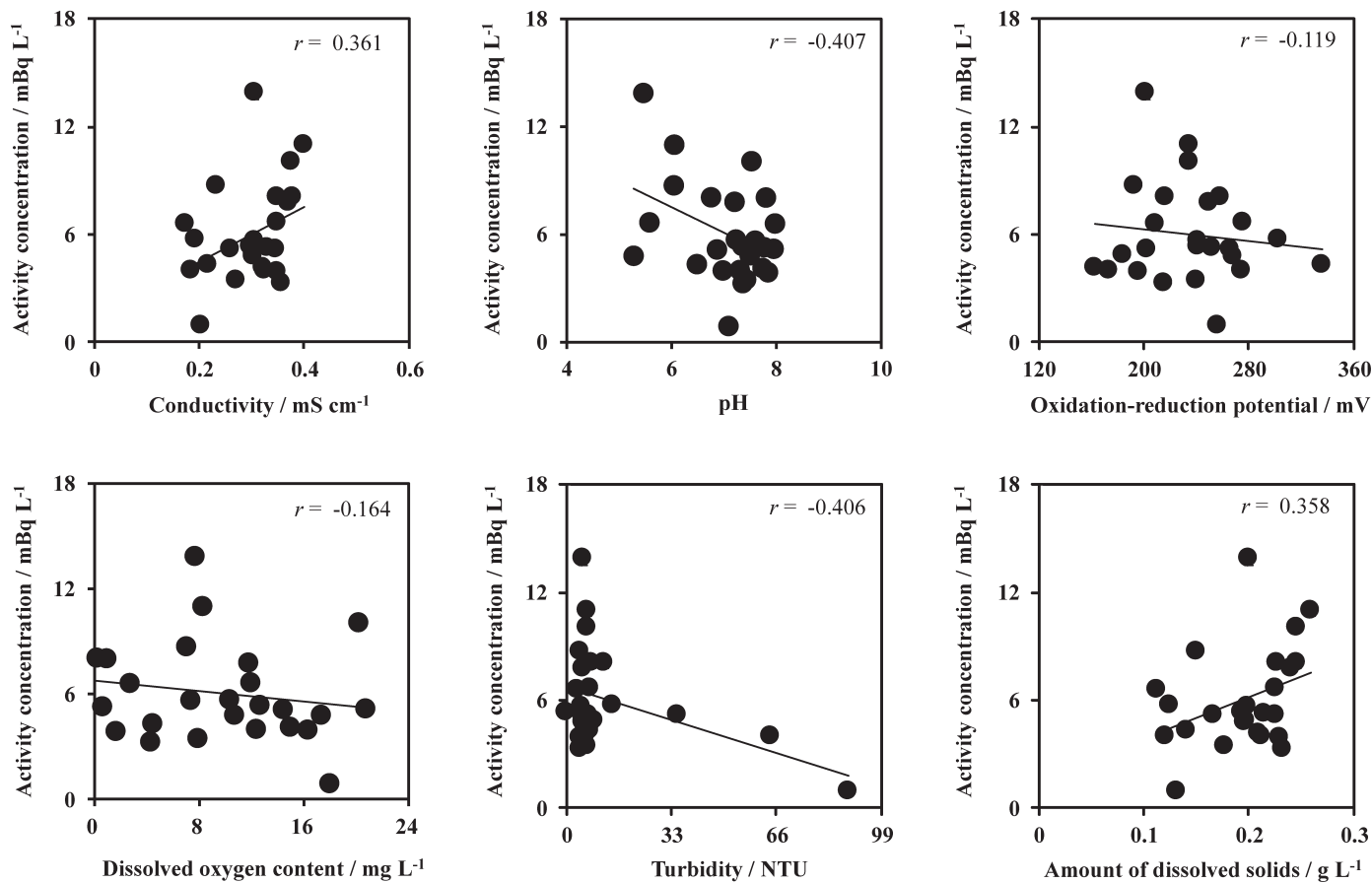

Fig. 4 Relationship between dissolved ${ }^{137} \mathrm{Cs}$ concentrations with the conductivity, $\mathrm{pH}$, oxidation-reduction potential, dissolved oxygen content, turbidity, and amount of dissolved solids in Tama river water.

$3 \cdot 2$ The relationship between concentration of radioactive caesium in river water and water quality

Since the aquatic environment may have an impact on the dissolved radioactive caesium concentration, we investigated the relationship between dissolved caesium concentration and water quality. Fig. 4 shows the relationship between dissolved ${ }^{137} \mathrm{Cs}$ concentration with conductivity, $\mathrm{pH}$, oxidation-reduction potential, dissolved oxygen content, turbidity, and amount of dissolved solids in the river water (from April 2013 to December 2015). The ${ }^{137}$ Cs concentration showed weak correlations with conductivity, $\mathrm{pH}$, turbidity, and amount of dissolved solids in the river water $(|r|=0.361-0.407)$. While the correlation coefficients between ${ }^{137} \mathrm{Cs}$ concentration with oxidation-reduction potential and dissolved oxygen content were -0.119 and -0.164 , respectively, and there was no correlation between these.
3.3 Temporal changes in radioactive caesium concentration in sediments

Table 3 shows the activity concentrations of radioactive caesium in sediments sampled at Shukugawara during 2012-2016. Radioactive caesium concentration in sediments was considerably higher than that in river water, indicating that much of the radioactive caesium in the Tama river existed in the sediments. The activity ratio of ${ }^{134} \mathrm{Cs} /{ }^{137} \mathrm{Cs}$ corrected at the time of March 15, 2011 was 1.02 \pm 0.13 . Fig. 5 shows temporal changes in the radioactive caesium concentration in sediments. As days passed after the nuclear accident, radioactive caesium concentration in the sediments decreased. This is likely due to weathering effect of the sediments, much like the radioactive caesium in river water. The concentration of radioactive caesium in sediments was expressed by the function of the days since the nuclear accident: $C_{\mathrm{Cs}-134}=214 \mathrm{e}^{-0.00241 d}$ and $C_{\mathrm{Cs}-137}=215 \mathrm{e}^{-0.00156 d}$, and the correlation coefficient $r$ was estimated by 
Table 3 Activity concentration of radioactive caesium in sediments sampled at Shukugawara

\begin{tabular}{|c|c|c|c|}
\hline \multirow{2}{*}{ Sampling date } & \multicolumn{2}{|c|}{ Activity concentration $( \pm 1 \sigma) / \mathrm{Bq} \mathrm{kg}^{-1}$} & \multirow{2}{*}{$\begin{array}{l}{ }^{134} \mathrm{Cs} /{ }^{137} \mathrm{Cs} \\
\text { activity ratio* }\end{array}$} \\
\hline & ${ }^{134} \mathrm{Cs}$ & ${ }^{137} \mathrm{Cs}$ & \\
\hline 2012.6 .7 & $171.6 \pm 3.0$ & $242.1 \pm 5.5$ & 1.04 \\
\hline 2012.6 .29 & $25.1 \pm 1.3$ & $39.4 \pm 2.3$ & 0.954 \\
\hline 2012.7 .4 & $131.5 \pm 2.6$ & $192.4 \pm 4.8$ & 1.03 \\
\hline 2012.7 .26 & $50.8 \pm 1.8$ & $77.3 \pm 3.2$ & 1.00 \\
\hline 2012.8 .17 & $24.4 \pm 1.3$ & $41.5 \pm 2.4$ & 0.919 \\
\hline 2012.8 .29 & $36.0 \pm 1.5$ & $54.6 \pm 2.8$ & 1.04 \\
\hline 2012.9 .20 & $51.2 \pm 1.8$ & $82.3 \pm 3.2$ & 1.00 \\
\hline 2012.10 .10 & $71.6 \pm 2.4$ & $97.6 \pm 3.6$ & 1.20 \\
\hline 2012.10 .23 & $97.8 \pm 2.6$ & $143.0 \pm 4.7$ & 1.13 \\
\hline 2012.11 .13 & $44.7 \pm 1.8$ & $72.4 \pm 3.3$ & 1.04 \\
\hline 2012.11 .27 & $29.8 \pm 1.4$ & $47.8 \pm 2.5$ & 1.06 \\
\hline 2012.12 .18 & $22.8 \pm 1.3$ & $42.3 \pm 2.3$ & 0.936 \\
\hline 2013.4.12 & $41.2 \pm 1.7$ & $90.1 \pm 3.5$ & 0.876 \\
\hline 2013.5 .14 & $137.7 \pm 2.9$ & $264.4 \pm 5.8$ & 1.03 \\
\hline 2013.6.11 & $29.7 \pm 1.6$ & $52.7 \pm 2.9$ & 1.14 \\
\hline 2013.7 .11 & $43.6 \pm 2.0$ & $77.9 \pm 3.5$ & 1.16 \\
\hline 2013.8 .2 & $35.4 \pm 1.8$ & $65.9 \pm 3.2$ & 1.13 \\
\hline 2013.9.27 & $43.0 \pm 2.4$ & $108.0 \pm 3.8$ & 0.880 \\
\hline 2013.10 .31 & $15.9 \pm 1.4$ & $42.4 \pm 2.2$ & 0.871 \\
\hline 2013.11 .7 & $17.4 \pm 1.5$ & $38.2 \pm 2.3$ & 1.04 \\
\hline 2013.11 .14 & $18.0 \pm 1.6$ & $39.8 \pm 2.4$ & 1.05 \\
\hline 2013.11 .21 & $14.0 \pm 1.2$ & $38.2 \pm 2.1$ & 0.850 \\
\hline 2014.4 .30 & $13.5 \pm 1.3$ & $41.2 \pm 2.4$ & 0.870 \\
\hline 2014.5.30 & $13.6 \pm 1.3$ & $38.9 \pm 2.3$ & 0.955 \\
\hline 2014.6.27 & $12.6 \pm 1.2$ & $33.0 \pm 2.2$ & 1.07 \\
\hline 2014.7.29 & $11.0 \pm 1.1$ & $34.4 \pm 2.1$ & 0.916 \\
\hline 2014.9 .16 & $10.5 \pm 0.7$ & $30.0 \pm 1.4$ & 1.05 \\
\hline 2014.11 .28 & $5.3 \pm 0.6$ & $21.2 \pm 1.2$ & 0.797 \\
\hline 2015.1 .29 & $6.4 \pm 0.6$ & $23.1 \pm 1.3$ & 0.938 \\
\hline 2015.3 .12 & $6.8 \pm 0.8$ & $21.3 \pm 1.6$ & 1.12 \\
\hline 2015.5 .22 & $5.1 \pm 0.8$ & $24.6 \pm 1.8$ & 0.772 \\
\hline 2015.6 .10 & $5.9 \pm 0.8$ & $18.6 \pm 1.6$ & 1.18 \\
\hline 2015.7 .14 & $5.5 \pm 0.7$ & $26.6 \pm 1.6$ & 0.798 \\
\hline 2015.8 .26 & $10.7 \pm 1.2$ & $46.6 \pm 2.8$ & 0.919 \\
\hline 2015.9 .12 & $5.8 \pm 0.8$ & $19.3 \pm 1.7$ & 1.23 \\
\hline 2015.10 .22 & $1.7 \pm 0.5$ & $5.85 \pm 1.0$ & 1.22 \\
\hline 2015.11 .2 & $1.0 \pm 0.3$ & $3.59 \pm 0.6$ & 1.19 \\
\hline 2015.11 .25 & $4.3 \pm 0.7$ & $15.1 \pm 1.4$ & 1.24 \\
\hline 2015.12 .23 & $3.3 \pm 0.6$ & $13.8 \pm 1.3$ & 1.05 \\
\hline 2016.1.26 & $4.6 \pm 0.7$ & $22.4 \pm 1.6$ & 0.940 \\
\hline
\end{tabular}

*Activity concentration was corrected at the time of March $15,2011$.

$r=-0.784$ and $r=-0.757$. This results a high degree of correlation between the concentration of radioactive caesium in sediments and the number of days since the nuclear accident. Furthermore, there was a temporary increase in radioactive caesium concentration in the sediments during rainfall events (August 26, 2015) as with suspended radioactive caesium. However, the influence of rainfall for radioactive caesium in the sediments was smaller than that for suspended radioactive caesium.

The residence half-life of radioactive caesium in sediment were 0.788 and 1.22 years for ${ }^{134} \mathrm{Cs}$ and ${ }^{137} \mathrm{Cs}$, respectively, and these are shorter than the residence half-life of radioactive caesium in the river water.

\subsection{Chemical analysis of radioactive caesium in sediments}

At the beginning of the monitoring, radioactive caesium concentration in sediments changed drastically but became stable with time. This indicates that radioactive caesium is incorporated into sediments in a stable form. Therefore, in order to survey the chemical state of radioactive caesium in sediments, the sequential extraction was employed on the sediments. Table 4 shows the sequential extraction result of sediments sampled in May 2013 and August 2015. Here, IE is a fraction in which metallic elements exist as water-soluble compounds, and metallic elements are easily released from samples into the water. $\mathrm{CB}$ is a fraction in which metallic elements are bonded with carbonate ions, where metallic elements are released to the environment by mild acids such as rainwater. $\mathrm{OX}$ is a fraction in which metallic elements are incorporated in Fe and Mn oxides, and metallic elements are eluted in a reducing atmosphere in which the structures of Fe and Mn oxides are destroyed. OB is a fraction in which metallic elements bond with organic materials and sulfide compounds, where metallic elements are chemically stable but gradually eluted under an oxidizing atmosphere. RES is a fraction where metallic elements are chemically stable, and it is not likely that metallic elements are released and dispersed into the environment. Radioactive caesium was detected in the OX, $\mathrm{OB}$, and RES fractions in both samples, but not in the IE and CB fractions. In other words, radioactive caesium was found in sediments in a state that is not easily dissolved in water. This result was similar to extraction result by adsorption experiment. ${ }^{25}$ With increased days, radioactive caesium concentrations 


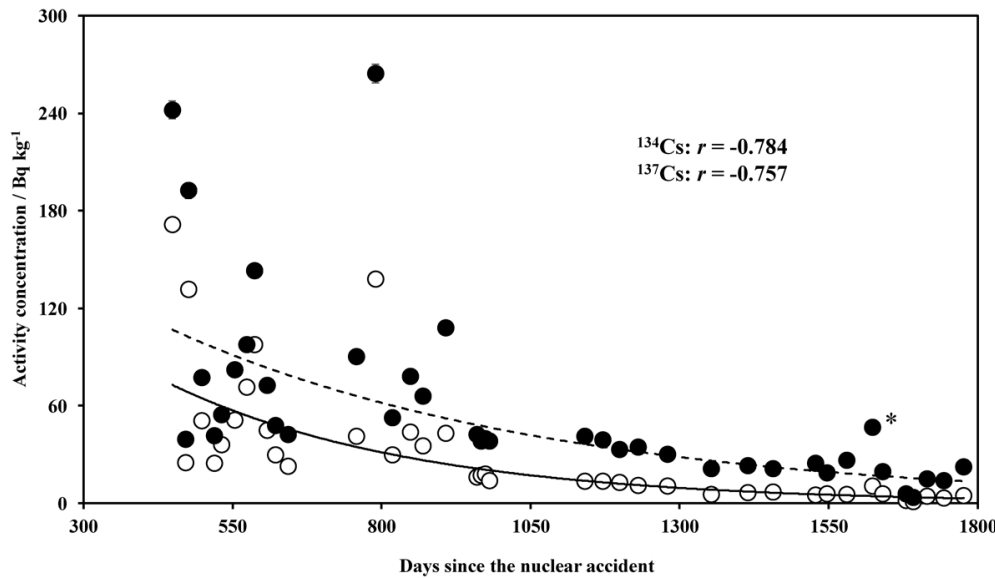

Fig. 5 Temporal changes of ${ }^{134} \mathrm{Cs}(\bigcirc)$ and ${ }^{137} \mathrm{Cs}(\bigcirc)$ concentrations in sediment sampled at Shukugawara. *: Sampled at August 26, 2015. Error bar: Standard deviation.

Table 4 Chemical form of ${ }^{137} \mathrm{Cs}$ in sediment sampled at Shukugawara

\begin{tabular}{cccccc}
\hline \multirow{2}{*}{ Sampling date } & \multicolumn{5}{c}{ Elution ratio, \% } \\
\cline { 2 - 6 } & IE & CB & OX & OB & RES \\
\hline May 14, 2013 & 0 & 0 & 24.4 & 12.5 & 63.1 \\
August 26, 2015 & 0 & 0 & 20.1 & 3.0 & 76.9 \\
\hline
\end{tabular}

IE: Ion-exchangeable, CB: bond to carbonates, OX: bond to $\mathrm{Fe}$ and $\mathrm{Mn}$ oxides, $\mathrm{OB}$ : bond to organics and sulfide compounds, RES: residuals.

of $\mathrm{OX}$ and $\mathrm{OB}$ fractions decreased, while radioactive caesium concentration in the RES fraction increased. Radioactive caesium in the soil tended to increase with the number of days (since the nuclear accident) in the insoluble RES fraction. ${ }^{11)}$ We guess that the radioactive caesium in the RES fraction of sediment sample is chemically stable with lapse of time.

3.5 The relationship between radioactive caesium in sediments and sediment components

Since certain sediment components might contribute to maintenance of radioactive caesium, we investigated the relationship between dissolved caesium concentrations with constituent elements and crystal phase. First, we analyzed the constituent elements of sediments using X-ray fluorescence analysis. Fig. 6 shows the relationship between ${ }^{137} \mathrm{Cs}$ concentration in sediments and $\mathrm{K}, \mathrm{Ti}, \mathrm{Mn}, \mathrm{Fe}, \mathrm{Zn}$,
$\mathrm{Rb}, \mathrm{Sr}$, and $\mathrm{Zr}$ concentrations. The concentration of ${ }^{137} \mathrm{Cs}$ showed a negative strong correlation with alkali metals $(\mathrm{K}$ and $\mathrm{Rb})$ concentration $\left(r_{\mathrm{K}}=-0.724\right.$ and $\left.r_{\mathrm{Rb}}=-0.767\right)$, and a positive strong correlation with $\mathrm{Mn}, \mathrm{Fe}$ and $\mathrm{Zn}$ concentration $\left(r_{\mathrm{Mn}}=0.906\right.$, $r_{\mathrm{Fe}}=0.932$ and $\left.r_{\mathrm{Zn}}=0.854\right)$. Sediments mainly consist of minerals and organic materials. Since $\mathrm{K}, \mathrm{Mn}, \mathrm{Fe}, \mathrm{Zn}$, and $\mathrm{Rb}$ are commonly contained in minerals, adsorption of radioactive caesium to sediments is highly influenced by the mineral species that constitute the sediments. Therefore, we conducted a crystal phase analysis of sediments. Fig. 7 shows X-ray diffraction patterns of sediment samples collected in November 2013. Quartz $\left(\mathrm{SiO}_{2}\right)$, plagioclase $\left(\mathrm{NaAlSi}_{3} \mathrm{O}_{8}-\mathrm{CaAl}_{2} \mathrm{Si}_{2} \mathrm{O}_{8}\right)$, halloysite $\left(\mathrm{Al}_{2} \mathrm{Si}_{2} \mathrm{O}_{5}(\mathrm{OH})_{4}\right)$, biotite $\left(\mathrm{KMg}_{3} \mathrm{AlSi}_{3} \mathrm{O}_{10}(\mathrm{OH}, \mathrm{F})\right.$ $\left.\mathrm{K}(\mathrm{Mg}, \mathrm{Fe})_{3} \mathrm{AlSi}_{3} \mathrm{O}_{10}(\mathrm{OH}, \mathrm{F})_{2}-\mathrm{KFe}_{3} \mathrm{AlSi}_{3} \mathrm{O}_{10}(\mathrm{OH}, \mathrm{F})_{2}\right)$, muscovite $\left(\mathrm{KAl}_{2} \mathrm{AlSi}_{3} \mathrm{O}_{10}(\mathrm{OH})_{2}\right)$, and kaolinite $\left(\mathrm{Al}_{4} \mathrm{Si}_{4} \mathrm{O}_{10}(\mathrm{OH})_{8}\right)$ were detected. Minerals that contain $\mathrm{K}$ and $\mathrm{Fe}$ were detected, but minerals containing $\mathrm{Mn}, \mathrm{Zn}$, and $\mathrm{Rb}$ were not detected. This is because those concentration was extremely low. Biotite is a mineral that contains both $\mathrm{K}$ and $\mathrm{Fe}$, and radioactive caesium is easily adsorbed onto this mineral. ${ }^{26)}$ Since ${ }^{137} \mathrm{Cs}$ concentration had a negative correlation with $\mathrm{K}$ concentration and a positive correlation with $\mathrm{Fe}$ 

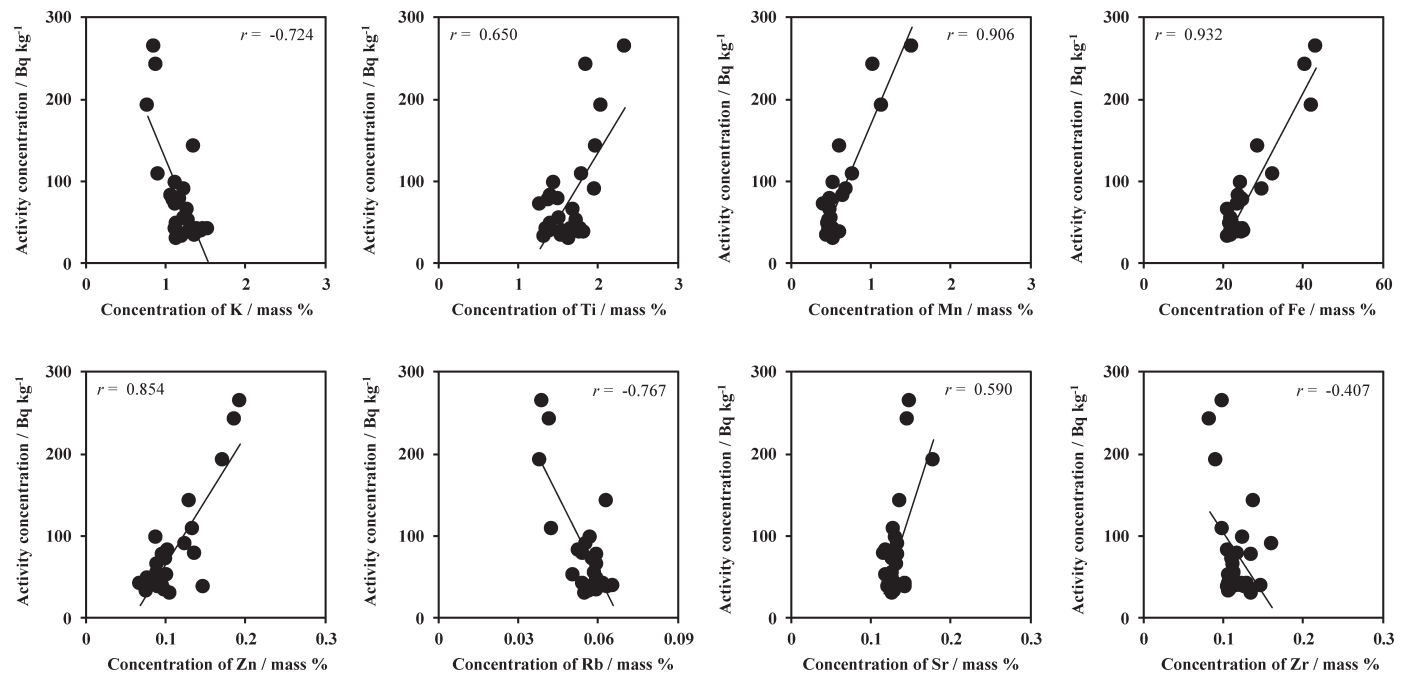

Fig. 6 Relationship between ${ }^{137} \mathrm{Cs}$ concentrations with $\mathrm{K}, \mathrm{Ti}, \mathrm{Mn}, \mathrm{Fe}, \mathrm{Zn}, \mathrm{Rb}, \mathrm{Sr}$, and $\mathrm{Zr}$ concentrations in sediment. Error bar: Standard deviation.

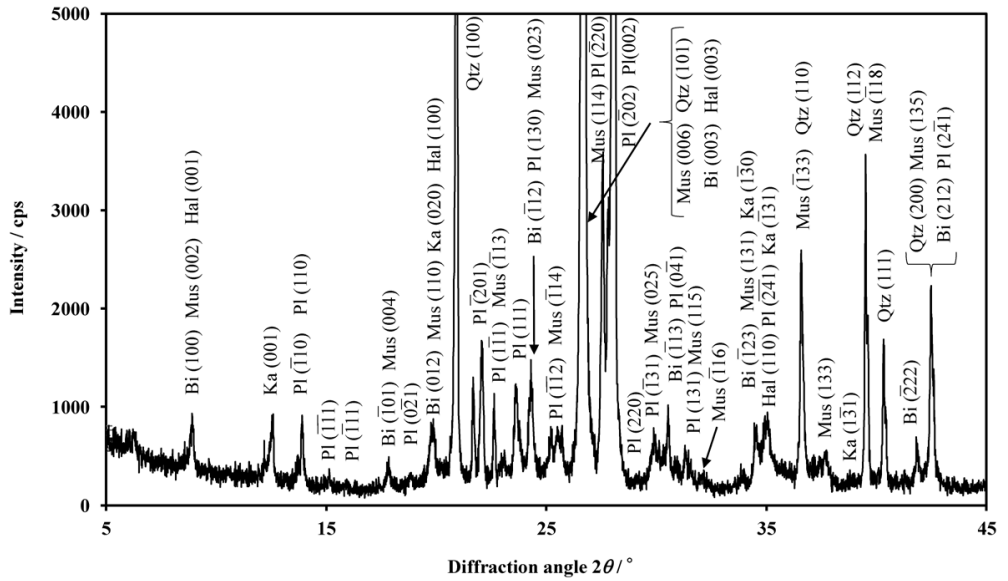

Fig. 7 X-ray diffraction pattern of sediment sampled at Shukugawara, Tama river. Bi: Biotite, Hal: Halloysite, Ka: Kaolinite, Mus: muscovite, Pl: Plagioclase, Qtz: Quartz.

concentration, it is likely that radioactive caesium substitutes for the $\mathrm{K}$ ions in biotite or is adsorbed via lattice defects. It is considered that because of magnetic interaction with $\mathrm{Fe}$, radioactive caesium is first adsorbed onto the sediment's surface and then gradually incorporated into the crystal lattice of minerals and becomes stable.

\section{Conclusions}

We conducted monitoring of radioactive cae- sium in the Tama river, which is a low-dose area, to track the behavior of radioactive caesium. The concentration of radioactive caesium in river water and sediment decreased exponentially in a short period of time less than half-life. Radioactive caesium concentration was found to be highest in sediments, followed by the dissolved and then suspended state. When sequential extraction analysis was performed on the sediments, radioactive caesium was present in a stable chemical form but not in a water-soluble 
form. As a result of elemental analysis, concentration of radioactive caesium in sediment had strong correlations with $\mathrm{K}, \mathrm{Mn}, \mathrm{Fe}, \mathrm{Zn}$, and $\mathrm{Rb}$ concentration. In addition to this, from the results of crystal phase analysis, there is possibility that radioactive caesium was incorporated in biotite.

\section{Acknowledgments}

This research was partially supported by the Tokyu Foundation for Better Environment (2015-03).

\section{References}

1) Tsuji, H., Yasutaka, T., Kawabe, Y., Onishi, T., et al., Distribution of dissolved and particulate radiocesium concentrations along rivers and the relations between radiocesium concentration and deposition after the nuclear power plant accident in Fukushima, Water Res., 60, 15-27 (2014)

2) Sakaguchi, A., Tanaka, K., Iwatani, H., Chiga, H., et al., Size distribution studies of ${ }^{137} \mathrm{Cs}$ in river water in the Abukuma riverine system following the Fukushima Dai-ichi Nuclear Power Plant accident, J. Environ. Radioact., 139, 379-389 (2015)

3) Yasutaka, T., Kawabe, Y., Kurosawa, A. and Komai, $\mathrm{T}$., Monitaring dissolved radioactive cesium in Abukuma River in Fukushima Prefecture, Proceedings of International Symposium on Environmental monitoring and dose estimation of residents after accident of TEPCO's Fukushima Daiichi Nuclear Power Stations, Part 2-11 (2012)

4) Ochiai, S., Ueda, S., Hasegawa, H., Kakiuchi, H., et al., Effects of radiocesium inventory on ${ }^{137} \mathrm{Cs}$ concentrations in river waters of Fukushima, Japan under base-flow conditions, J. Environ. Radioact., 144, 86-95 (2015)

5) Kato, H. and Onda, Y., Temporal changes in the transfer of accidentally released ${ }^{137} \mathrm{Cs}$ from tree crown to the forest floor after the Fukushima Daiichi Nuclear Power Plant accident, Prog. Nucl. Sci. Tech., 4, 18-22 (2014)

6) Teramage, M. T., Onda, Y., Kato, H. and Gomi, $\mathrm{T}$., The role of litterfall in transferring Fukushimaderived radiocesium to a coniferous forest floor, $\mathrm{Sci}$. Total Environ., 490, 435-439 (2014)

7) Sakai, M., Gomi, T., Naito, R. S., Negishi, J. N., et al., Radiocesium leaching from contaminated litter in forest streams, J. Environ. Radioact., 144, 15-20 (2015)

8) Saito, K., Tanihata, I., Fujiwara, M., Saito, T., et al., Detailed deposition density maps constructed by large-scale soil sampling for $\gamma$-ray emitting radioactive nuclides from the Fukushima Dai-ichi Nuclear Power Plant accident, J. Environ. Radioact., 139, 308-319 (2015)

9) Ohta, T., Mahara, Y., Kubota, T. and Igarashi, T., Erratum to aging effect of ${ }^{137} \mathrm{Cs}$ obtained from ${ }^{137} \mathrm{Cs}$ in the Kanto loam layer from the Fukushima Nuclear Power Plant accident and in the Nishiyama loam layer from the Nagasaki A-bomb explosion, Anal. Sci., 29, 941-947 (2013)

10) Takahashi, J., Tamura, K., Suda, T., Matsumura, R., et al., Vertical distribution and temporal changes of ${ }^{137} \mathrm{Cs}$ in soil profiles under various land uses after the Fukushima Dai-ichi Nuclear Power Plant accident, J. Environ. Radioact., 139, 351-361 (2015)

11) Ochi, K., Fujii, K., Hagiwara, K., Ohbuchi, A., et al., Characterization of radiocesium in soil sampled at the Koshinetsu and Kanto regions, Bunseki Kagaku, 66, 175-180 (2017)

12) Misumi, K., Tsumune, D., Tsubono, T., Tateda, Y., et al., Factors controlling the spatiotemporal variation of ${ }^{137} \mathrm{Cs}$ in seabed sediment off the Fukushima coast: Implications from numerical simulations, J. Environ. Radioact., 136, 218-228 (2014)

13) Inoue, M., Kofuji, H., Fujimoto, K., Furusawa, Y., et al., Delivery mechanism of ${ }^{134} \mathrm{Cs}$ and ${ }^{137} \mathrm{Cs}$ in seawater off Sanriku Coast, Japan, following the Fukushima Dai-ichi NPP accident, J. Environ. Radioact., 137, 113-118 (2014)

14) Kumamoto, Y., Aoyama, M., Hamajima, Y., Murata, A., et al., Impact of Fukushima-derived radiocesium in the western North Pacific Ocean about ten months after the Fukushima Dai-ichi Nuclear Power Plant accident, J. Environ. Radioact., 140, 114-122 (2015)

15) Matsunaga, T., Amano, H. and Yanase, N., Discharge of dissolved and particulate ${ }^{137} \mathrm{Cs}$ in the Kuji River, Japan, Appl. Geochem., 6, 159-167 (1991)

16) Hirose, K., Aoyama, M. and Sugimura, Y., Plutonium and cesium isotopes in river waters in Japan, J. Radioanal. Nucl. Chem., 141, 191-202 (1990)

17) Nagao, S., Kanamori, M., Ochiai, S., Tomihara, S., et al., Export of ${ }^{134} \mathrm{Cs}$ and ${ }^{137} \mathrm{Cs}$ in the Fukushima river systems at heavy rains by Typhoon Roke in September 2011, Biogeosciences, 10, 6215-6223 (2013)

18) Ueda, S., Hasegawa, H., Kakiuchi, H., Akata, N., 
et al., Fluvial discharges of radiocaesium from watersheds contaminated by the Fukushima Dai-ichi Nuclear Power Plant accident, Japan, J. Environ. Radioact., 118, 96-104 (2013)

19) Zhu, Y. G. and Smolders, E., Plant uptake of radiocaesium: A review of mechanisms, regulation and application, J. Exp. Bot., 51, 1635-1645 (2000)

20) Evans, D. W., Alberts, J. J. and Clark, R. A. III, Reversible ion-exchange fixation of cesium-137 leading to mobilization from reservoir sediments, Geochim. Cosmochim. Acta, 47, 1041-1048 (1983)

21) Tanaka, K., Iwatani, H., Sakuguchi, A., Fan, Q., et al., Size-dependent distribution of radiocesium in riverbed sediments and its relevance to the migration of radiocesium in river systems after the Fukushima Daiichi Nuclear Power Plant accident, J. Environ. Radioact., 139, 390-397 (2015)

22) Koike, Y., Suzuki, R., Ochi, K., Hagiwara, K., et al.,
Radioactivity analysis using commercially available chemical reagents as calibration sources, Bunseki Kagaku, 66, 263-270 (2017)

23) Aoyama, M. and Hirose, K., Radiometric determination of anthropogenic radionuclides in seawater, $R a$ dioactivity in the Environment, 11, 137-162 (2008)

24) Tessier, A., Campbell, P. G. C. and Bisson, M., Sequential extraction procedure for the speciation of particulate trace metals, Anal. Chem. Chem., 51, 844-851 (1979)

25) Qin, H., Yokoyama, Y., Fan, Q., Iwatani, H., et al., Investigation of cesium adsorption on soil and sediment samples from Fukushima Prefecture by sequential extraction and EXAFS technique, Geochem. J., 46, 297-302 (2012)

26) Kogure, T., Mukai, H. and Motai, S., Identification of Cs-sorbing minerals in Fukushima, Chikyu Kagaku, 49, 195-201 (2015)

\title{
要旨
}

\section{多摩川における放射性セシウムの定点観測とキャラクタリゼーション}

\author{
萩原健太 $^{1,2, \dagger}$, 越智康太郎 ${ }^{3}$, 小池裕也 ${ }^{1}$ \\ 1 明治大学理工学部応用化学科, \\ 2 明治大学大学院理工学研究科, \\ ${ }^{3}$ 日本原子力研究開発機構福島環境安全センター \\ ${ }^{\dagger}$ kenhagi@meiji.ac.jp \\ 2020 年 4 月 1 日 受付 \\ 2021 年 1 月 28 日 受理
}

多摩川中流域で定点観測を実施し、河川水及び底質中の放射性セシウムの挙動を 2012 年から 2016 年にかけて調査した。河川水及び底質中の放射性セシウム濃度は、時間とともに減少した。 これらの放射性セシウムの滞留半減期は ${ }^{134} \mathrm{Cs}$ で $0.778-1.50$ 年、 ${ }^{137} \mathrm{Cs}$ で $1.22-2.17$ 年であり、放射 性セシウムの風化現象が確認された。雨により水中が懸濁すると、懸濁態放射性セシウム濃度が 一時的に増加した。一方、溶存態放射性セシウムはこの影響を受けなかった。放射性セシウム濃 度は河川水よりも底質の方がかなり高く、多摩川の放射性セシウムの多くが底質に存在していた。 底質に関して逐次抽出、元素および結晶相分析を行い、放射性セシウムの化学状態と底質への吸 着メカニズムを調査した。底質中の放射性セシウムは安定した化学形態で存在しており、バイオ タイトが放射性セシウムを取り込んでいる可能性があった。 